Revolution and World Politics 


\section{Also by Fred Halliday}

Arabia without Sultans

Iran: Dictatorship and Development

The Ethiopian Revolution (with Maxine Molyneux)

The Making of the Second Cold War

Cold War, Third World: An Essay on Soviet-American Relations

Revolutions and Foreign Policy: The Case of South Yemen 1967-1987

Arabs in Exile: Yemeni Migrants in Urban Britain

Rethinking International Relations

From Potsdam to Perestroika: Conversations with Cold Warriors

Islam and the Myth of Confrontation: Religion and Politics in the Middle East 


\title{
Revolution and World Politics
}

The Rise and Fall of the Sixth Great Power

\author{
Fred Halliday
}




\section{$\Leftrightarrow$}

(C) Fred Halliday 1999

All rights reserved. No reproduction, copy or transmission of this publication may be made without written permission.

No paragraph of this publication may be reproduced, copied or transmitted save with written permission or in accordance with the provisions of the Copyright, Designs and Patents Act 1988, or under the terms of any licence permitting limited copying issued by the Copyright Licensing Agency, 90 Tottenham Court Road, London W1P 9HE.

Any person who does any unauthorised act in relation to this publication may be liable to criminal prosecution and civil claims for damages.

The author has asserted his right to be identified as the author of this work in accordance with the Copyright, Designs and Patents Act 1988.

First published 1999 by

MACMILLAN PRESS LTD

Houndmills, Basingstoke, Hampshire RG21 6XS

and London

Companies and representatives

throughout the world

ISBN 978-0-333-65329-6

DOI 10.1007/978-1-349-27702-5

A catalogue record for this book is available from the British Library.

$\begin{array}{rrrrrrrrrr}10 & 9 & 8 & 7 & 6 & 5 & 4 & 3 & 2 & 1 \\ 08 & 07 & 06 & 05 & 04 & 03 & 02 & 01 & 00 & 99\end{array}$

Copy-edited and typeset by Povey-Edmondson Tavistock and Rochdale, England 
To Maxine 


\section{Contents}

Preface

xiii

1 Introduction: Revolutions and the International

The Unpeaceful Origins of a Peaceful World

The Centrality of Revolution

Structure in Mass Upheavals $\quad 7$

Normative Debates: The Challenge to Sovereignty 10

Analytic Focuses: Understanding and Explanation $\quad 16$

Social Revolutions in Retrospect

\section{PART I THE INTERNATIONALIST ENGAGEMENT}

\section{An Alternative Modernity: The Rise and Fall of}

'Revolution'

1989: The Cunning of History Returns 27

The Evolution of a Concept $\quad 29$

The Metahistorical Idea $\quad 35$

Distinctive Events $\quad 38$

The Communist Variant $\quad 40$

Explicit Criteria: The Responses of Social Science 45

Implicit Criteria: Challenges of History 47

The Collapse of European Communism 51

3 Internationalism in Theory: A World-Historical Vision $\quad 56$

Revolution and 'World History' 56

The Necessity of an International Vision $\quad 59$

The Rise of Revolutionary Cosmopolitanism 64

Marx's Reformulation: 'Proletarian Internationalism' 72

Capitalism and Revolution: The Communist Manifesto 77

In the Age of Imperialism: Lenin 82

Challenge from the Third World $\quad 88$

A Contradictory Vision $\quad 91$ 
4 Internationalism in Practice: Export of Revolution 94

Transgressing Diplomacy: The Export of Revolution 94

France: 'La Grande Nation' $\quad 99$

Russia: The Communist International 103

China: The Dialectics of 'Anti-Hegemonism' 110

Cuba: The Tricontinental 116

Iran: Muslim Solidarity, the Umma and the Mustazafin 124

$\begin{array}{ll}\text { Solidarity and its Limits } & 129\end{array}$

5 The Antinomies of Revolutionary Foreign Policy 133

Revolution and Diplomacy: The 'Dual Policy' 133

Continuity and Rupture 140

Revolution and Counter-Revolution: The Chimera of Primacy

State and Society: An Internationalised Conflict 143

Internationalism and Nationalism 146

Heterogeneity and Homogeneity 152

Calculations of Deviation 156

\section{PART II REVOLUTIONS AND THE INTERNATIONAL SYSTEM}

6 The International as Cause

Conceptual Reassessments: State, Ideology,

International

Causes of Revolution: (i) Theories in Social Science 165

Causes of Revolution: (ii) Axes of Debate 171

The Weakening of States 174

$\begin{array}{ll}\text { Conjunctural Crises } & 177\end{array}$

The Impact of Ideas $\quad 179$

Mobilisation of the Oppressed 182

Appearances of Insulation: England, Iran 184

The 'International' Revisited 190

7 Revolutions and International History $\quad 192$

Revolution and International History 192

1517-1648 194

$1760-1815 \quad 195$

$\begin{array}{ll}1905-91 & 196\end{array}$ 
Cold War Conflict and Third World Revolution 198

The Most Dangerous Moment: October $1962 \quad 200$

Legacies of Communism 202

The Impact on International Relations 203

Challenges to the System 205

8 Counter-Revolution $\quad 207$

Reaction Across Frontiers 207

Varieties of Counter-Revolution 210

The Compulsion to Intervene 212

The Incoherences of Counter-Revolution 221

Limits on Power 224

Why States Intervene 226

The Domino Theory: A Second Look 230

9 War and Revolution 234

Similarities, Distinctions $\quad 235$

Wars as Precipitant 237

Success and Failure: War as Consequence 241

War as Instrument: (i) Armed Insurrection 243

War as Instrument: (ii) The Politics of Nuclear

Weapons 246

War as Instrument: (iii) Guerrilla War 247

War as Instrument: (iv) The War of Revolutionary

Offensive 254

'Never Invade a Revolution': Mass Mobilisation and

Revolutionary Defence 256

A Contingent Relationship 258

10 Systemic Constraints: Revolutionary 'Transformation' and Autarky 261

Post-Revolutionary Transformation: International

Constraints 261

Self-Reliance: The Theory 270

Phase I: The Revolutionary Rupture 273

Phase II: The Impasses of Delinking 280

Phase III: The 'Middle Road' 283

Exogenous Constraints 285

The Revenge of Capital 287 
PART III CONCLUSIONS: THEORETICAL AND HISTORICAL

11 Challenges to Theory 293

International Relations: Competing Theories 293

(i) 'Dissatisfaction': Henry Kissinger 294

(ii) The Challenge to 'International Society': David Armstrong 296

(iii) Heterogeneity and Misperception: Kim Kyung-won 299

(iv) The Pertinence of Politics: Stephen Walt 301

(v) The Balance of Power Disturbed: Richard Rosecrance 303

(vi) Transnationalism and Violence: James Rosenau 304

(vii) Anti-Systemic Movements: Immanuel Wallerstein 306

Theoretical Assumptions: International Relations, Revolution, Society 308

The Three Dimensions of International Relations 311

Social Movements: Classes as Transnational Actors $\quad 315$

The Inescapable Context: Combined and Uneven

Development

12 Revolutions in World Politics 323

The Great Displacement $\quad 323$

Fissures of Modernity 326

Historical Record $\quad 330$

Revolution in the Age of Globalisation 331

The Permanence of Unrest 334

$\begin{array}{ll}\text { Notes } & 339\end{array}$

Select Bibliography $\quad 378$

Index 396 
La victoire, en chantant, nous ouvre la barrière

La Liberté guide nos pas.

Et du nord au midi, la trompette guerrière

A sonné l'heure des combats.

Tremblez, ennemis de la France.

Rois ivres de sang et d'orgueil,

Le peuple souverain s'avance:

Tyrans descendez au cercueil . . .

Sur ce fer, devant Dieu, nous jurons à nos pères,

A nos épouses, à nos mères,

D'anéantir les oppresseurs.

En tous lieux, dans la nuit profonde

Plongeant l'infame royauté

Les Français donneront au monde

Et la paix et la liberté

(Popular song of the French revolution, in Marcel Merle, Pacifisme et Internationalisme XVIIe-XXe siècles, Paris: Armand Colin, 1966, p. 160)

A young soldier spoke to us in German. 'The Brotherhood Grave', he explained. 'Tomorrow we shall bury here five hundred proletarians who died for the Revolution.'

He took us down into the pit. In frantic haste swung the picks and shovels, and earth-mountains grew. No one spoke. Overhead the night was thick with stars, and the ancient Imperial Kremlin wall towered up immeasurably.

'Here in this holy place,' said the student, 'holiest of all Russia, we shall bury our most holy. Here where are the tombs of the Tsars, our Tsar - the People - shall sleep ...' His arm was in a sling, from a bullet wound gained in the fighting. He looked at it. 'You foreigners look down on us Russians because so long we tolerated a medieval monarchy,' he said. 'But we saw that the Tsar was not the only tyrant in the world; capitalism was worse, and in all the countries of the world capitalism was Emperor . . Russian revolutionary tactics are best. . .'

(John Reed, Ten Days That Shook the World, Harmondsworth: Penguin, 1977, p. 227) 
In the Name of Almighty God, crusher of tyrants and champion of the oppressed. 'We desired to be gracious to those who have been oppressed on earth, and to make them leaders, and to make them inheritors.' (Koran). This is the voice of right, the voice of the oppressed, this is the voice of the Islamic Republic of Iran. Muslims everywhere, we transmit our programmes to you from Tehran, the bastion of the Islamic revolution, so that they will be a light for all oppressed people everywhere. We pledge to remain loyal to our Islamic mission, the mission of right, justice and freedom. This is Tehran, voice of the Islamic Republic of Iran.

(Opening announcement of Radio Tehran broadcasts in Arabic, BBC Summary of World Broadcasts, Part 4, The Middle East and North Africa, ME/7675/A2 21 June 1984) 


\section{Preface}

Revolutions are important events for individual countries and for the politics of the world. They are events of immense political and moral contradiction, occasions at once for the heroic and the idealistic, and for the cynical, the cruel and the destructive. Revolutions do not achieve what they set out to attain, but in an age where revolutions appear to be events of another time, it has to be remembered how and why millions of people fought, struggled and died for the cause of radical change. In the words of Edward Thompson, we need to rescue revolution 'from the immense condescension of posterity'. What equally cannot be denied is their formative influence on the world in which we live, and in the shaping of the societies and political systems of today. Writing in 1854, when world politics was dominated by the pentarchy, the rule of five great powers, and Europe was preoccupied by the Crimean War, Karl Marx argued that it was a sixth great power, revolution, which would prevail over the other five. ${ }^{1}$ It was a power which acted as much against states as through them, as much through ideas and social change as through diplomacy and war. The extent of that sixth great power's impact forms the focus of this study.

Every book has a personal element in it, and this one is no exception. One central argument made below is that revolutionaries, for all their exaggeration and tactical accommodations, mean much of what they say. This is as true for the international dimensions, the subject of this book, as for the domestic. The belief that revolutionaries do mean what they say was, of course, long held by those who supported revolutions. It was a belief challenged, quite properly, not only by the course of events, but also by recognition of the constraints, the failures, the limits of what revolutions achieved. The pendulum then swung in another direction - towards seeing revolutionaries as practitioners of Realpolitik, or of national interest little different from their non-revolutionary predecessors, or as people only interested in gaining and keeping power. Later sociologists and political scientists theorised this in 
terms of the preponderance of structure over agency. These qualifications of the role of agency need to be borne in mind: but they do not override the fact that, from the French revolutionaries in the 1790 s to Iran in the 1980 s, revolutionary states have formulated farreaching goals for change in both the domestic and international contexts. What this commitment leads to, and how far those in other countries follow them, is the central question examined in this book.

The question of the international dimensions of revolution hung over the second half of the twentieth century. The world I grew up in, that of the 1950s and 1960s, was one in which the claims of revolutionaries, and of those opposed to them, dominated much of world politics. This was an era of Cold War, of Third World revolution, and of growing tension, of opportunity and disunity, within the communist world. The great crisis of the communist movement, the moment from which in retrospect its internal dissolution began, was the secret speech by Soviet leader Nikita Khrushchev in 1956 denouncing the crimes of his predecessor Joseph Stalin. From this followed not only the split with China, in the early 1960s, and the breaking away of the Western European communist parties in the $1970 \mathrm{~s}$, but also that inner dissolution, and loss of faith, which was to end in the disintegration of the USSR in 1991. These were years of continued dispute within the communist world - the extended polemics between Russia and China of the early 1960s, the frenzied mobilisations of the Cultural Revolution in China, the controversy that divided Western communism following the criminal Soviet invasion of Czechoslovakia in 1968. Yet even as the Soviet Union came to face the truth about its own horrendous past, and as its international following began to erode, others, in the less developed world, remained gripped by the aspiration to make revolutions and construct states and societies radically different from those of the West. The 1960s and 1970s were decades in which the impact of revolution reverberated through the Third World, be it in the aftermath of the Cuban revolution of 1959 - I remember the first TV interview with Castro as he spoke on the eve of the capture of Havana. Later came the charged atmosphere surrounding the war in Vietnam in the late 1960s.

Much of my own work was taken up with upheavals in the Third World. In 1968 I spent a month in Cuba during which I witnessed two of the contrasted moments of that revolution's relation to the international: a speech by Fidel Castro in Oriente province inau- 
gurating the village of Nancahuazú, named after the village in Bolivia where Guevara had set up his revolutionary base: and the throttled response of the Cuban state to the political opening in Prague, accompanied by its stifling of debate within. A great admirer of the Cuban revolution, the veteran Italian journalist Saverio Tutino, then correspondent in Havana of Unita, told me: 'The atmosphere here is as bad as in Stalin's Russia in 1952.' While studying Middle East politics, I visited the Palestinian guerrillas in Jordan in 1969. In 1970 I embarked on a visit to the newly independent People's Republic of South Yemen and to the neighbouring region of Dhofar, in the Sultanate of Oman; the mountains of Dhofar, source of the frankincense of the ancient world, were at that time controlled by Maoist guerrillas. These South Arabian revolutionary movements, and the broader context of the Arabian Peninsula and the Persian Gulf, were to be the subject of later books - Arabia without Sultans, Iran: Dictatorship and Development and of my doctoral research on South Yemen, Revolution and Foreign Policy. In 1977-8, together with my partner Maxine Molyneux, I visited Ethiopia, then in the grip of civil war in Eritrea, and of inter-state war with Somalia: this resulted in our The Ethiopian Revolution.

If much of the emphasis of the 1960s and 1970s was on radical movements of the secular left - nationalist and communist - the 1980s were dominated by the rise of contestatory movements of Islamist orientation, above all in Iran. In the revolutionary Tehran of summer 1979 all the features of a modern revolution could be seen - mass meetings in the grounds of the university, buildings transformed into centres of radical activity, rhetorical assertions of solidarity with the oppressed of the world, the formation of a new militarised, and coercive, revolutionary regime. Under the chandeliers of the former imperial foreign ministry, I argued with then Foreign Minister Ibrahim Yazdi about the goals of the Islamic revolution. What has never ceased to strike me, and what I have tried to reflect in this book, is that for all the very substantial differences which the Iranian case exhibited in comparison with other revolutions there was much - in cause, development and language - that it had in common with them. ${ }^{2}$

The story of revolution in the twentieth century is haunted by 1917 and its aftermath. I first visited the Soviet Union in July 1982, in the last months of Brezhnevite 'stagnation', and then returned through the increasingly uncharted years of Gorbachev and his 
successors. The events of 1989-91 were to provide another, dramatic, chapter in the history of revolutions, and of the decisive intervention of peoples into politics. Nothing could more vividly illustrate the import of the collapse of communism in the period 1989-91 than the experience of cities where the old order had crumbled. To walk through streets in Budapest or Moscow that had been only months before ruled by communism, to see the collection of deposed statues - Lenin, Dzerzhinksy, Kalinin - in the garden of the House of Artists in Moscow, to cross at the former Checkpoint Charlie where the Berlin wall once stood and which I had often seen, or visit the gardens of the Lubkovic Palace, the German embassy, in Prague where thousands of East Germans had sought refuge in 1989, was to feel the passage of history before one's eyes. It seemed as if all that the Bolshevik revolution had meant for world history, and indeed all that 'Revolution' had meant, was now reduced to nothing. Demonstrators in Red Square carried the banner, a rebuttal of communist triumphalism about the advances of the Soviet state: '70 Years - On the Road to Nowhere'. In a meeting with the Russian sociologist Tatiana Zaslavskaya I asked her what, in her opinion, would be the significance of the Bolshevik revolution a generation hence: 'Nothing', she replied, and after a pause added, 'except nostalgia for great power status, and for social equality'.

The collapse of communism was, of course, only a European phenomenon: in China the Communist Party still ruled, but here too its authority was being eroded from within. In 1995 I had the occasion to teach at the People's University of Beijing: for 10 yuan, around one British pound, one could climb the stairs to the podium overlooking Tienanmen square and stand on the spot where, in October 1949, Mao Tse-tung announced that China had arisen. I do not know what that history, and clamour, meant to the crowds of young Chinese walking the square in front of me, and where eight years before student protesters had been slain in their hundreds: to my mind, it was part of the challenge that I have tried to address in this book. I asked a Chinese colleague what he now thought of Mao. 'Mao was an ignorant person. He did not brush his teeth. He was a cruel man, who killed millions of people. But I owe him my very existence: without the revolution he made, my father, who was from a poor peasant background, could never have afforded to marry. I would never have been born.' 
This concern with political upheavals and with their international consequences was matched by an attempt to understand the broader significance of the revolutions of modern history. As a student at the School of Oriental and African Studies in the period 1967-9 I began research on the comparative political study of revolutions. At that time there were certain books that shaped my interest in this issue: Barrington Moore's The Social Origins of Dictatorship and Democracy, Edgar Snow's Red Star Over China, and above all Franz Borkenau's World Communism, an incisive and comprehensive account of the rise of an international communist movement and its manipulation by the Soviet state. Later books were to develop the themes of this literature - I would mention, above all, on the sociological side Theda Skocpol's States and Social Revolutions, and in the charting of international revolution Jorge Castañeda's Utopia Unarmed.

In the late 1960s I also worked on the papers of the historian of the Russian revolution Isaac Deutscher, later published as Russia, China and the West. Deutscher had been a member of the opposition within the Polish communist party. He had remained loyal to the ideals of his youth, but had become amongst the most powerful critics of Stalin, and of the system, within the USSR and within the communist movement as a whole, that Stalin had created. Deutscher's biography of Stalin, published in 1949, remains as powerful a critique of the USSR, domestically and internationally, as any written in the subsequent half century. Deutscher, like Borkenau, was acutely sensitive to the ways in which revolutions both claim and subordinate an international following. He was a member of a communist party, that of Poland, whose leadership had been murdered by Stalin in the purges. The questions that Deutscher raised - the ideological origins of revolutions, the links between the French and twentieth-century upheavals, the emergence of post-revolutionary bureaucracy and dictatorship, the longer-run evolution of post-revolutionary societies - are ones that framed, and continue to frame, my approach to these questions. Deutscher did not live to see the outcome of the communist period in the Soviet Union and Eastern Europe: his expectations that these societies they could in some way be transformed into something at once democratic and revolutionary, have not been fulfilled. They were to prove unfounded. But the approach which he took historical, comparative, interpretative, above all critical - and which 
I discussed through many conversations with his wife Tamara, is one that has more than stood the test of time.

No topic of this kind is ever thought through on one's own. From the 1960s onwards I had the good fortune to belong to institutions that provided a context for reflection, and much argument, on these issues: first New Left Review, and then the Transnational Institute, both sources of immense intellectual stimulation. In 1983 I began teaching at the London School of Economics, and some time later began an MSc course on the international dimensions of revolutions. The debt I owe to the successive years of students on that course and to those who went on to do research related to the subject-matter of that course is unmeasurable. So too is my debt to those who have over the past two decades so developed the academic study of revolutions, in both its sociological and international dimensions: the literature that one has to work on today, itself enhanced by a flood of material following the collapse of communism, adds to the stimulation and the challenge of writing on this subject. I have tried in this book to relate this literature to two other benchmarks: one the Marxist tradition, the most serious engagement with revolution in modern social thought; the other historical events themselves, and the role within history of ideas, beliefs, myths. My writing in this and previous books has been strongly influenced by the Marxist interpretation of the modern world, and by its examination of the role of social movements, and protest, in the shaping of it. Above all it has emphasised that all modern phenomena have to be seen in the context of their overarching context, that of capitalism and of the contradictions it generates. Theodor Adorno said of fascism, that those who did not wish to speak of capitalism should not speak of it either. I would say the same of revolution, and of international relations: both are formed by capitalist modernity. Marxism has been associated both with great insights and with great illusions: I have tried to write in the spirit of the first, while avoiding the disasters of the second. How far I have been successful, or consistent, is for others to say. As for history, it remains both source and arbiter, a corrective to all theories and an inspiration to analysis.

Among the many individuals to whom I would wish to express gratitude I would mention Masood Akhavan Kazemi, Mariano Aguirre, Domingo Amuchastegui, Matthew Anderson, Perry Anderson, David Armstrong, Anthony Barnett, Robin Blackburn, Wilfred Burchett, Peter Calvert, Carmen Claudín, Mike Davis, Wolfgang 
Deckers, Tamara Deutscher, Luis Fernandes, Jon Halliday, Eric Hobsbawm, Monty Johnstone, Nikki Keddie, Saul Landau, Margot Light, Arno Mayer, Francis Mulhern, Justin Rosenberg, Stuart Schram, Teodor Shanin, Hazel Smith, Geoffrey Stern, Göran Therborn, Saverio Tutino, and Pere Vilanova. Jennifer Chapa of the Department of International Relations at LSE was a model of tact and endurance in the preparation of the manuscript for publication. Nick Bisley read the completed manuscript with exemplary editorial and conceptual vigilance. Financial support for teaching replacement was generously provided by the Suntory and Toyota International Centres for Economics and Related Disciplines at LSE.

My greatest debt, in this as in all other respects, is to Maxine Molyneux, who has lived through this history and these debates with me, and who has endured many visits to inhospitable and perilous places. She has been an inexhaustible source of support, ideas, criticism and inspiration. That this book is dedicated to her is a small, but heartfelt, recognition of what her partnership and love have meant to me.

\section{London}

Fred Halliday

\section{Notes}

1. 'The European War', New York Daily Tribune, 2 February 1854.

2. 'The Iranian Revolution in Comparative Perspective' in Fred Halliday, Islam and the Myth of Confrontation (London: I.B. Tauris, 1996). 